\title{
LATE WEICHSELIAN PERIGLACIAL FEATURES IN SOUTH-EASTERN FINLAND AND THE SURROUNDINGS OF LAKE LADOGA IN RUSSIA
}

\author{
JOAKIM DONNER and IRINA DELUSIN
}

\begin{abstract}
DONNER, JOAKIM and DELUSIN, IRINA, 1995. Late Weichselian periglacial features in south-eastern Finland and the surroundings of Lake Ladoga in Russia. Bull. Geol. Soc. Finland 67, Part II, 65-72.

Ice-wedge casts recorded from the Salpausselkä moraines in south-eastern Finland show that there was permafrost in this zone at the time of the Younger Dryas Stadial. The few sites with pocket involutions north and east of Lake Ladoga indicate that even this area had permafrost at the same time. Other signs of a periglacial environment are the stone pavements with ventifacts, underneath coversands, both in the Salpausselkä zone as well as outside it. Coversands and dunes were accumulated before a closed vegetation covered the area in the beginning of the Holocene.
\end{abstract}

Key words: periglacial features, fossil ice wedges, stone pavements, cover sands, Pleistocene, Weichselian, Younger Dryas, Southeastern Finland, Karelia, Russia.

Joakim Donner, Department of Geology, P.O.Box 11, FIN-00014 University of Helsinki, Finland.

Irina Delusin, St. Petersburg Branch of the Institute of Oceanology, Russian Academy of Sciences, I Linija 30, St. Petersburg 199053, Russia.

\section{INTRODUCTION}

The Fennoscandian moraines were formed during the standstills or readvances of the ice margin for the most part roughly at the time of the Younger Dryas Stadial at the end of the Late Weichselian, during the cold climatic oscillation before the onset of the Flandrian warm stage. Because of the cold climate in Younger Dryas time there was a periglacial zone outside the inner margin of the Fennoscandian moraines, a zone in which features typical for cold climatic conditions have been preserved, some of them formed in an environment with permafrost. The best evidence for this are 
the preserved features of patterned ground, in sections seen as ice-wedge casts and often associated with aeolian sediments accumulated as dunes or coversands by the strong winds in the periglacial zone with an open treeless vegetation. All these features have been recorded from outside the Fennoscandian moraines from areas that were dry land at the time of the withdrawal of the ice, such as from southern Sweden south of the Central Swedish moraines and from Norway from north of the Troms $\varnothing$-Lyngen moraine (Donner, 1995). However, fewer observations have been published of periglacial features from areas within and outside the zone of the Fennoscandian moraines in the south-eastern area of glaciation, which was also largely dry land during deglaciation. As this area is potentially a most suitable area for studies of periglacial features, an account is given here of the observations made in the area surrounding Lake Ladoga in Russia and of previously recorded sites in south-eastern Finland. The observations of the features in Russia were made during an excursion around Lake Ladoga arranged by the Division of Geology and Palaeontology of the Department of Geology, University of Helsinki, in June 1993.

The areas surrounding Lake Ladoga were deglaciated in Late Weichselian time. The Fennoscandian moraines are represented in southern Finland by the end moraines of Salpausselkä I and II. The withdrawal of the ice margin from these moraines took place already at about 10,600 B.P., whereas the climatic amelioration in south-eastern Finland, as demonstrated by biostratigraphical studies, took place at about 10,000 B.P. in radiocarbon years, or slightly earlier, thus close to the time defined as the lower boundary of the Flandrian, and also of the Holocene (Donner, 1995).

\section{SITES WITH PERIGLACIAL FEATURES}

The recorded sites with ice-wedge casts, listed in Table 1, are all at the surfaces of marginal glacio- fluvial accumulations of the Salpausselkä I and II moraines, usually represented by wide deltas or sandur-deltas (Fig. 1). The ice-wedge casts are covered by $50-60 \mathrm{~cm}$ of sediments of the former active layer, whereas some of the ice-wedge casts formed in the underlying permafrost are up to about $2 \mathrm{~m}$ deep and in places about $60 \mathrm{~cm}$ broad at the top. Most of the ice-wedge casts were formed after the accumulation of the sands and gravels in which they occur and are thus epigenetic. Some of them have a vertical layering, with the finest material in the centre, as a result of repeated filling in of the wedges with sediment (Fig. 2), similar to older ice-wedge casts reported from Central Europe (Eissmann, 1981). Some of the deep and narrow wedges may be syngenetic, formed during the accumulation of the sediments (West, 1977; Ehlers, 1994). A detailed classification of the icewedge casts in south-eastern Finland has not, however, been undertaken. At a few sites the pattern of the ice-wedge casts has been traced at the surface to show how it reflects a network of former tundra polygons (Aartolahti, 1970). In addition to the ice-wedge casts there are some sites where only narrow thermal contraction cracks occur, which have not had time to develop into broader wedge-shaped features.

Clear ice-wedge casts have only been reported from the two Salpausselkä moraines (Fig. 1). In addition to the ice-wedge casts there is other evidence of a periglacial environment in this zone. At a site in Tohmajärvi contortions below aeolian sand in a channel-fill sequence on top of glaciofluvial sediments related to the Salpausselkä I moraine were interpreted as periglacial involutions (Gibbard and Saarnisto, 1977). From three marginal formations of the Salpausselkäs, including the large formation of Jaamankangas at the junction of two ice lobes (Fig. 1, Table 1), stone pavements with ventifacts have been described (Markuse and Vesajoki, 1985). The pavements are all underneath a $10-40 \mathrm{~cm}$ thick layer of coversand, this being a fine aeolian sand. A similar sequence (Table 1) was described from an esker near Ilomantsi (Vesajoki, 1985). But here thin thermal contraction cracks extended into the 


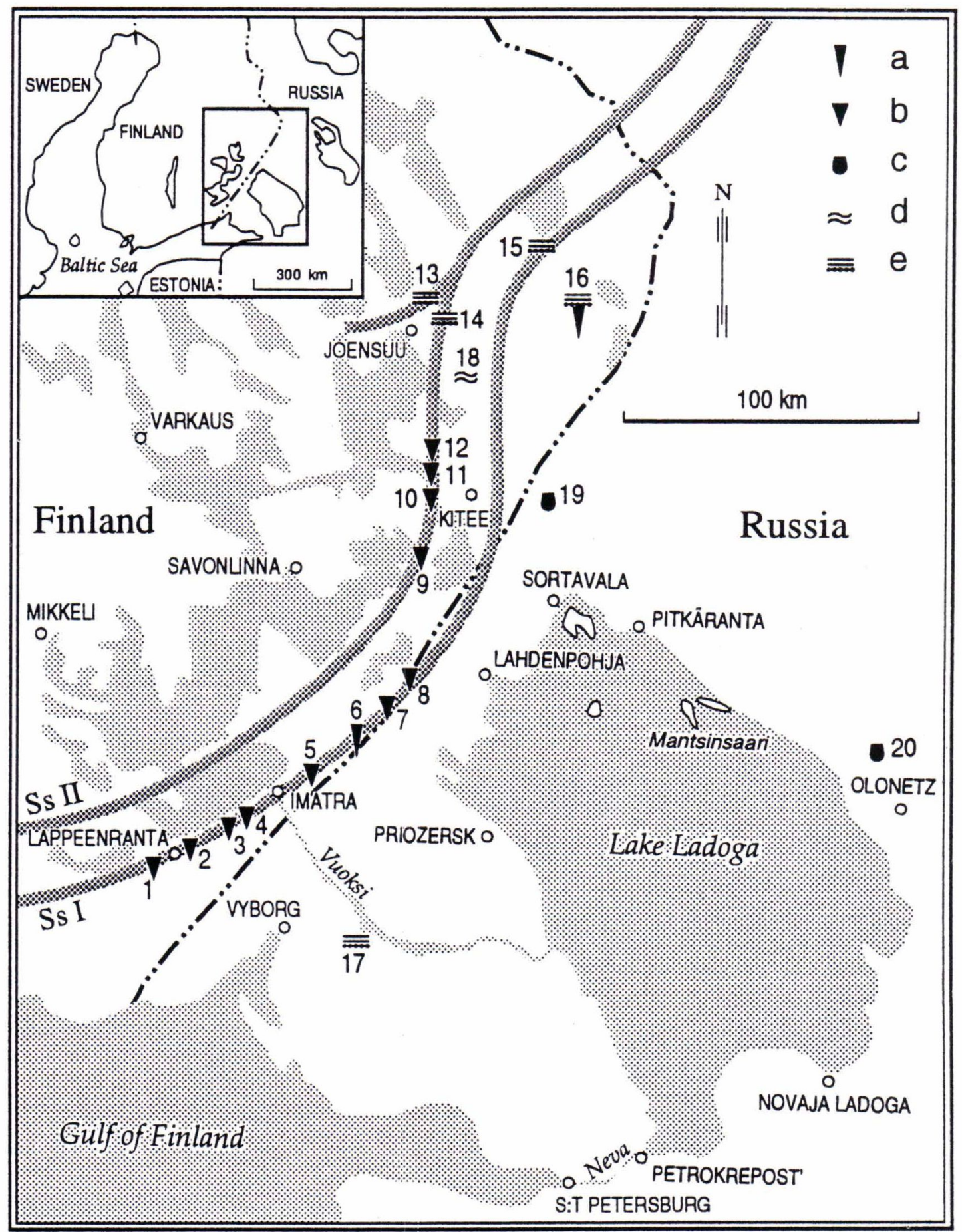

Fig. 1. Map showing sites with periglacial features (listed in Table 1). Symbols: a, thin thermal contraction cracks; $b$, ice-wedge casts; $c$, pocket involutions; $d$, contortions; e, coversand on top of stone pavement with ventifacts. 
Table 1. Sites with periglacial features shown on map in Fig. 1.

Ice-wedge casts and narrow thermal contraction cracks:

1. Ss I, Lappeenranta (Donner, Lappalainen and West, 1968).

2. Ss I, Lauritsala (Donner, Lappalainen and West, 1968).

3. Ss I, Joutsenonkangas (Aartolahti, 1970).

4. Ss I, Jänhiälä, Joutseno (Aartolahti, 1970).

5. Ss I, Immalankangas, Ruokolahti (Donner, Lappalainen and West, 1968).

6. Ss I, Laikko, Rautjärvi (Donner, Lappalainen and West, 1968).

7. Ss I, Änkilä, Simpele (Aartolahti, 1970).

8. Ss I, Koitsanlanhti (Aaartolahti, 1970).

9. Ss II. Haavisto, Kesälahti (Aartolahti, 1970).

10. Ss II. Puhos, Kitee (Aartolahti, 1970).

11. Ss II. Suorlahti, Kitee (Aartolahti, 1970).

12. Ss II. Tolosenmäki, Kitee (Aartolahti, 1970).

Coversands on top of stone pavements with ventifacts:

13. Jaamankangas (Markuse and Vesajoki, 1985).

14. Kruununkangas (Markuse and Vesajoki, 1985).

15. Palokangas / Selkäkangas (Markuse and Vesajoki, 1985).

16. Putkelansärkkä, Ilomantsi (Vesajoki, 1985), with thermal contraction cracks underneath stone pavement.

17. Äyräpää, Karelian Isthmus.

Involutions:

18. Kankaala, Tohmajärvi (Gibbard and Saarnisto, 1977), contortions.

19. Nurmoila, Olonetz / Aunus (Kivinen, 1971), pocket involutions.

20. Poikkola, Pälkjärvi, pocket involutions.

underlying sands from the stone pavement with ventifacts. The fine material of the coversand, here about $1 \mathrm{~m}$ thick on top of the stone pavement, is a suitable sediment for the nests of the sand martin (Riparia riparia), as seen in Fig. 3, and can therefore easily be identified in a section.

The coversand, which was described from sites with stone pavements, is a rather widespread surface sediment on higher ground in the foreland of the Salpausselkä moraines in south-eastern Finland (Mielonen, 1965). In addition to this fine aeolian material there are dunes both on the moraines and on their distal side from a time when the prevailing winds were from between the northwest and the north-east (Lindroos, 1972). The aeolian sediments in the region postdate the features of frost action they cover, but were here mostly accumulated in a periglacial environment (Gibbard and Saarnisto, 1977; Vesajoki, 1985). Here as elsewhere in Finland shore dunes continued to form later at the receding coastline as a result of the land uplift (Lindroos, 1972; Aartolahti, 1977).

In addition to the sites of periglacial features close to the Salpausselkä moraines only a few can be added from the surroundings of Lake Ladoga (Fig. 1). In Poikkola, Pälkjärvi, north of Lake Ladoga, 30-40 cm deep pocket involutions underneath a cover of nearly $1 \mathrm{~m}$ of sand and gravel were found in a section of a narrow esker (Fig. 4). The material in the pockets is finer than the surrounding sand into which they have penetrated, whereas the surface material is coarser. The pocket involutions are similar in shape to those described earlier by Kivinen (1971) from a section in the esker at Nurmoila north of Olonetz, east of Lake Ladoga (Fig. 1). The involutions, described by Kivinen as load casts, were up to $30 \mathrm{~cm}$ deep and consisted of finer material than the underlying sand. On the Karelian Isthmus between Lake 


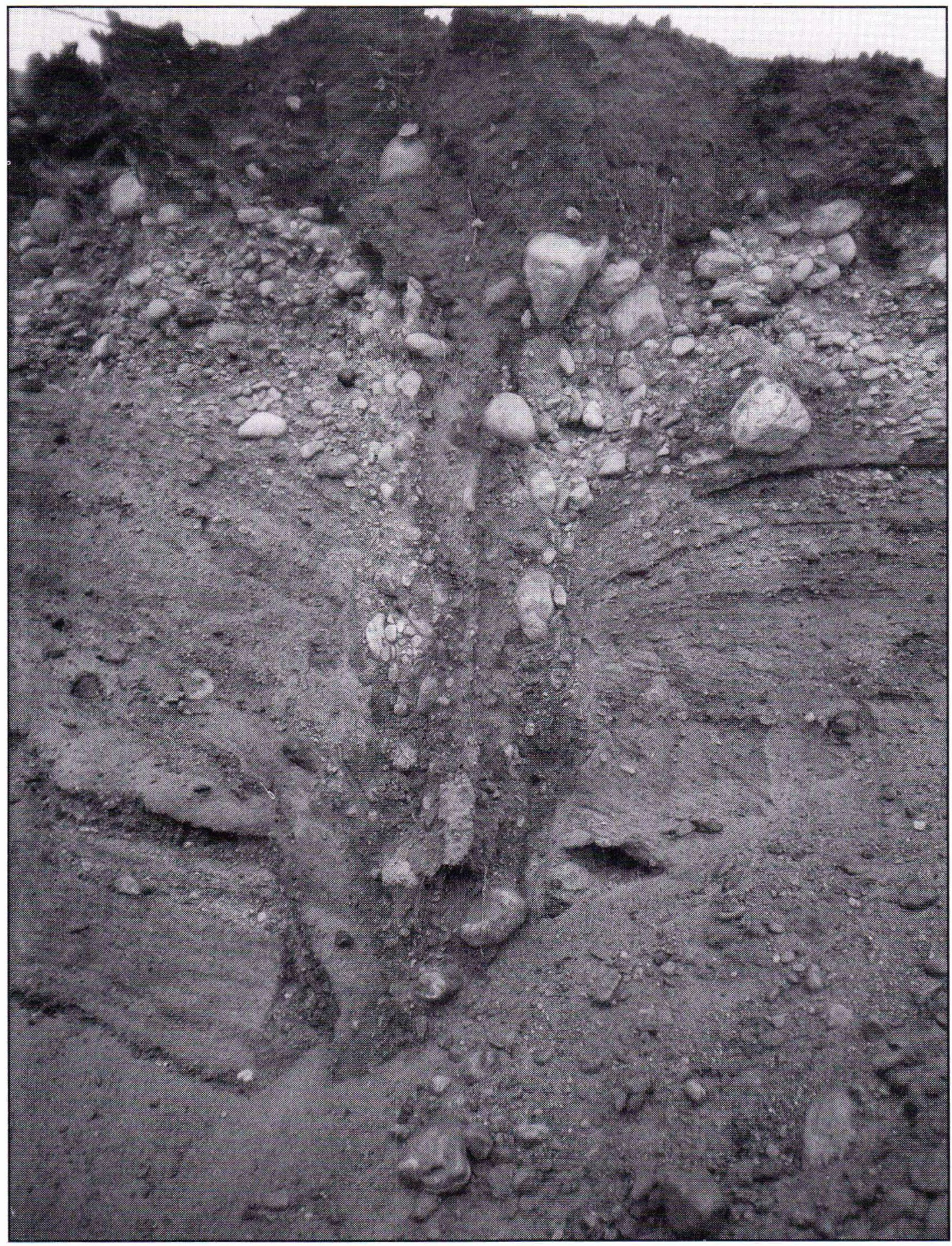

Fig. 2. A $2.5 \mathrm{~m}$ deep ice-wedge cast in glacio-fluvial sediments at Joutsenonkangas, Salpausselkä I (Donner, 1992, Fig. 2). 


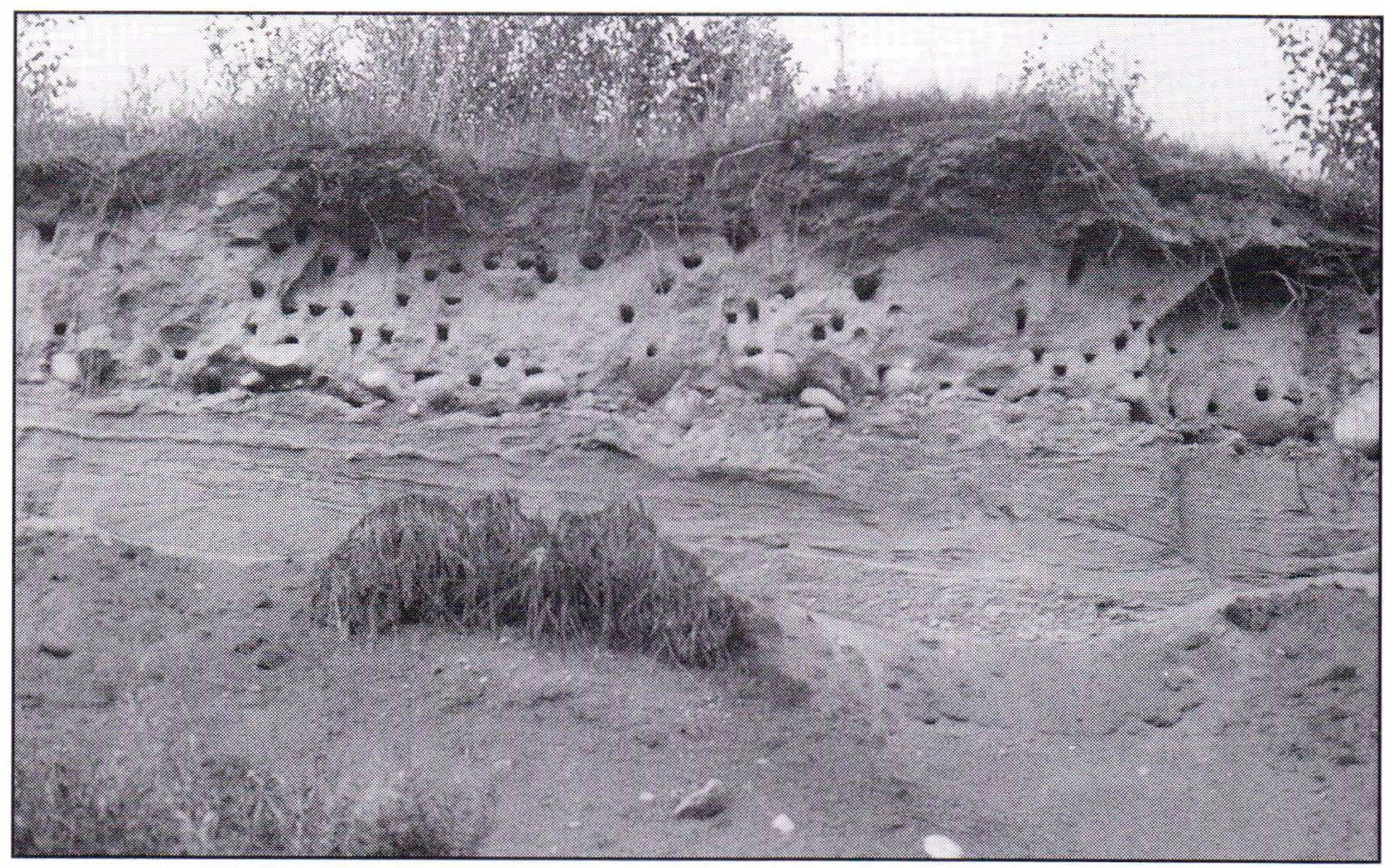

Fig. 3. Cover sand with nests of the sand martin on top of stone pavement in the esker of Putkelanharju, Ilomantsi.

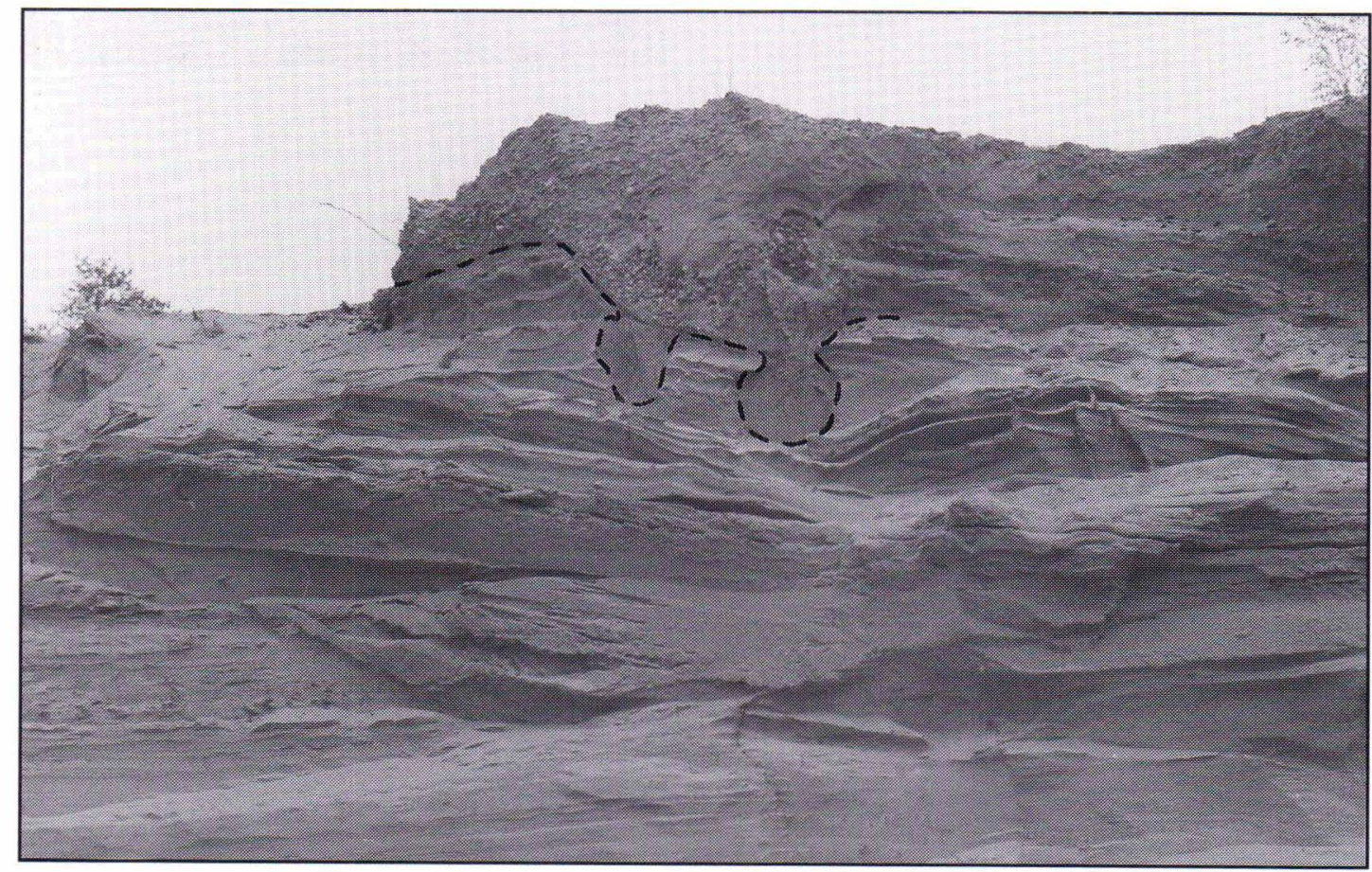

Fig. 4. Pocket involutions on top of esker at Poikkola, Pälkjärvi. 
Ladoga and the Gulf of Finland a section in the esker at Äyräpää has a surface layer of coversand on top of a stone pavement with wind-polished stones mantling the underlying glacio-fluvial sands and gravels (Fig. 5), similar to the abovementioned section in Ilomantsi (Fig. 3).

\section{CONCLUSIONS}

All the features that may be interpreted as having been formed in a periglacial environment have been found in the area dealt with at the surface of glacio-fluvial sands and gravels of the two Salpausselkä moraines in Finland or of eskers away from them. The ice-wedge casts recorded from the Salpausselkä moraines (Fig. 1) show that at least this narrow zone had a period with permafrost immediately after and partly even during their formation, before the general climatic amelioration resulting in the withdrawal of the ice margin from these moraines. Compared with the general glacial history of the region the cold period with permafrost can be correlated with the Younger Dryas Stadial. No indications of permafrost have been recorded from the area deglaciated inside the Salpausselkä moraines at the beginning of the Holocene.

The sites with pocket involutions are in an area deglaciated during the Allerød Interstadial before 11,000 B.P. (Donner, 1995), an area in which frost structures could develop during the subsequent Younger Dryas Stadial. The involutions are not as such evidence of permafrost (Washburn, 1973; West, 1977), but taking into account their occurrences on top of sands and gravels in eskers, without impermeable sediments, they were most likely formed in the active layer saturated with water at a time when there was permafrost underneath. If this conclusion is correct it means that there was permafrost, at least in some areas, north and east of Lake Ladoga in Younger Dryas time.

The stone pavements with ventifacts underneath coversands show that these features, common in the present Arctic (Washburn, 1973), were also

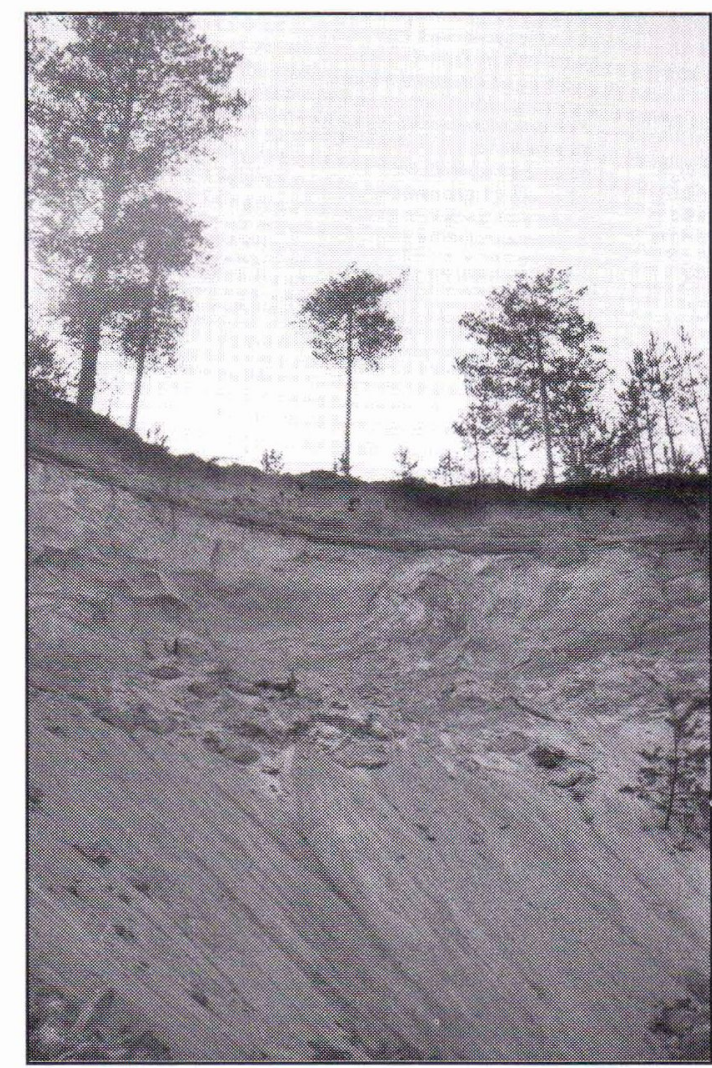

Fig. 5. Coversand on top of stone pavement in the esker at Äyräpää, Karelian Isthmus.

common in the former periglacial zone dealt with here. The coversands and dunes were deposited in the area on top of the periglacial structures and stone pavements at latest at the end of the Younger Dryas Stadial, before the land surface became covered with a closed vegetation at the beginning of the Holocene. As large parts of the Karelian Isthmus were submerged at the time of deglaciation, periglacial features, similar to those described above, are more likely to be encountered in the areas east and north-east of Lake Ladoga, which were mostly dry land at that time.

ACKNOWLEDGEMENTS: The authors want to thank Tuija Jantunen for drawing the map in Fig. 1 , and the participants in the excursion around Lake Ladoga in 1993 for their help in the field. 


\section{REFERENCES}

Aartolahti, T. 1970. Fossil ice-wedges, tundra polygons and recent frost cracks in southern Finland. Annales Academiae Scientiarum Fennicae A III 107, 26 pp.

Aartolahti, T. 1977. Lentohiekka Suomessa. Suomalainen Tiedeakatemia, Esitelmät ja pöytäkirjat 1976, 8395.

Donner, $J$. 1992. Is there evidence in the zone of the first Salpausselkä moraine in Finland of a transgression of the Baltic Ice Lake before its drainage? Sveriges Geologiska Undersökning Ca 81, 87-90.

Donner, J. 1995. The Quaternary history of Scandinavia. Cambridge University Press, $200 \mathrm{pp}$.

Donner, J., Lappalainen, V. and West, R.G. 1968. Ice wedges in south-eastern Finland. Geologiska Föreningens i Stockholm Förhandlingar 90, 112-116.

Ehlers, J. 1994. Allgemeine und historische Quartärgeologie. Stuttgart, Ferdinand Enke Verlag, 358 pp.

Eissmann, L. 1981. Periglaziäre Prozesse und Permafroststrukturen aus sechs Kaltzeiten des Quartärs. Altenburger Naturwissenschaftliche Forschungen 1, $171 \mathrm{pp}$.

Gibbard, P. and Saarnisto, M. 1977. Periglacial phenomena at Tohmajärvi, eastern Finland. Geologiska
Föreningens i Stockholm Förhandlingar 99, 295-298.

Kivinen, E. 1971. Pari valokuvaa kuormituksen aiheuttamista muutoksista hiekkamaassa. Geologi 1971 (4), 65.

Lindroos, $P$. 1972. On the development of late-glacial and post-glacial dunes in North Karelia, eastern Finland. Geological Survey of Finland, Bulletin 254, 85 pp.

Markuse, G. and Vesajoki, H. 1985. Periglasiaalisia ventifakteja Pohjois-Karjalasta (Summary: Periglacial ventifacts in northern Karelia, Finland). Geologi 1985 (4-5), 81-84.

Mielonen, M. 1965. Die Vaara-Siedlung in Nord-Karelien und ihre Beziehung zur Landwirtschaft. Fennia 93 (2), $171 \mathrm{pp}$.

Saarnisto, M. 1977. Deformational structures in the first Salpausselkä end moraine, Joutsenonkangas, southeastern Finland. Bulletin of the Geological Society of Finland 49, 65-72.

Vesajoki, H. 1985. Fossiilisten jääkiilojen kehityssarja Ilomantsissa (Summary: A developmental series of fossil ice wedges in Ilomantsi, eastern Finland). Geologi 1985 (9-10), 176-180.

Washburn, A.L. 1973. Periglacial processes and environments. Edward Arnold, 320 pp.

West, R.G. 1977. Pleistocene geology and biology, 2nd ed. London, Longman, 440 pp. 